\title{
Immune Alterations in Liver Cirrhosis: Its Relationship with Etiology, Child Pugh Stage and Malnutrition
}

\section{Marlen I. Castellanos ${ }^{1 *}$, Osvaldo R. Seijas ${ }^{1}$, Dayamí González¹, Mercedes Ronquillo², Maria del Rosario Abreu ${ }^{3}$, Sergio Ojeda $^{4}$}

${ }^{1}$ Gastroenterology Specialists, Institute of Gastroenterology. Havana. Cuba

${ }^{2}$ Allergy Specialist, Institute of Gastroenterology. Havana. Cuba

${ }^{3}$ Biostatistics Specialist, Institute of Gastroenterology. Havana. Cuba

${ }^{4}$ Clinical Laboratory Specialists, Institute of Gastroenterology. Havana. Cuba

\begin{abstract}
Background: Immune alterations in liver cirrhosis are variable and only a few have been correlated with the severity of the disease, malnutrition or its etiology.

Methods: A descriptive transversal study was carried out in 76 patients with liver cirrhosis predominantly of viral cause. According to the Child Pugh stage they were classified in A: 52, B:17 and C: 7 . The anthropometric evaluation included mid-arm circumference, triceps and subscapular skinfold thickness. The humoral immune alterations were evaluated by assessing serum immunoglobulin ( $A, M, G$ and $E$ ) and the complement components' $C 3$ and C4. Cellular immunity integrated a total lymphocyte count and the delayed intradermal hypersensitivity test. The statistical analysis included Pearson's Chi squared and non-parametric tests using the U Mann Whitney or Kruskal Wallis test.

Results: In the study group, the immunoglobulins were in normal range; however the complement components C3 and C4 showed a certain tendency to the inferior normal limit. Immunodeficiency was diagnosed in 28 patients $(36.8 \%)$. Statistical comparisons showed that C4 complement component was the principal factor affected with the lower values in alcoholic and viral group, whereas for the alcohol group, IgE was found at higher titles. The major immunological dysfunction was in Child C stage, found it in $71.4 \%$. Malnutrition was present in $63.2 \%$, but the analysis of the humoral immunity indicators according to the nutritional state only reported significant differences in the $\mathrm{C} 4$ average values. A higher percentage of immunodepressed in the undernourished was reflected, in comparison to the non-malnourished.
\end{abstract}

Conclusion: In liver cirrhosis, the major contribution to the distorted immune response is the Child Pugh stage while the malnutrition maybe has a possible influence.

Keywords: Liver Cirrhosis; Child Pugh; Immunodeficiency; Malnutrition

\section{Introduction}

The immune alterations in patients with liver cirrhosis vary, they are not universal and only a few have been able to be correlated with the severity of the disease or its prognosis. The best characterized alterations correspond to the inefficient bactericide action from the serum, opsonins and complement, altered function of neutrophils and to changes in the activity of the reticuloendothelial system[1].

On the other hand, individuals with cirrhosis are severely affected by malnutrition and are therefore susceptible to complications probably derived from humoral and cellular immunologic deficiencies [2-7]. Energy undernourishment in its diverse forms including the subclinical, compromises the resistance to external agents such as bacteria, viruses, fungus and also chemical agents in a severe way [8]. The recovery of immune functions after a nutritional substitution with supplements is encouraging and is another proof of the relationship between nutrition and immune state [9-13]. Cirrhotic patients have an increased intestinal permeability which enables the passage of endotoxins generated by gram negative bacteria from the intestine to the lymphatic and blood stream. The latter stimulates the liberation of mediators of the inflammatory response and nitric oxide, these being responsible in a great manner for the catabolic state and the hiperdynamic circulation of the disease [14].

The immune alterations and the repercussions on the nutritional state caused by alcohol in cirrhotic patients are known, however, investigations that evaluate this association in relation to other causes of cirrhosis like the viral and metabolic have been poorly explored [6].

Although the physiopathologic bases explain the relationship between undernourishment and immune alterations, the results obtained in the different studies related to cirrhosis of the liver are still insufficient mainly because the precise mechanism of immunocompetence in the disease is not well established. The present study was carried out to identify the main immune alterations in patients with cirrhosis of the liver in relationship with the stage of the disease, undernourishment and its etiology.

\section{Material and Methods}

A descriptive transversal study was carried out at the Institute of Gastroenterology in Havana, Cuba from March 2008 to May 2010 in 76 patients with a confirmed diagnosis of liver cirrhosis (clinical, laboratory tests and histomorphologic), divided into three groups according to the etiology, 55 viral ( 34 by hepatitis $C$ virus, 17 by hepatitis $B$ virus and 4 co-infected by both viruses), 11 alcoholics and 10 of a predominantly metabolic cause. A similar distribution of male/female (38/38) was presented with an average age of $50.1 \pm 8.8$ years, classified according to

*Corresponding author: Dr. Marlen I. Castellanos, Calle 25 No.503 e/ Hel. Vedado CP 10400. Plaza de la Revolución, La Habana, Cuba, Tel: 053-7-8325067,E-mail: docegastro@infomed.sld.cu

Received August 09, 2011; Accepted October 19, 2011; Published October 21 2011

Citation: Castellanos MI, Seijas OR, González D, Ronquillo M, del Rosario Abreu M, et al. (2011) Immune Alterations in Liver Cirrhosis: Its Relationship with Etiology Child Pugh Stage and Malnutrition. J Nutr Disorders Ther 1:101. doi:10.4172/21610509.1000101

Copyright: ( 2011 Castellanos MI, et al. This is an open-access article distributed under the terms of the Creative Commons Attribution License, which permits unrestricted use, distribution, and reproduction in any medium, provided the original author and source are credited. 
the Child Pugh stage with A: 52, B:17 and C: 7. Although the viral cause predominated in both sexes, alcoholism was more in males. Patients with autoimmune diseases, severe allergies, immunosuppressing diseases, presently taking immunosuppressing/immunomodulation drugs (including steroids) or antivirals in the previous six months, immunodeficiency of any type, human immunodeficiency virus (HIV), pregnancy and uncontrolled chronic diseases were excluded.

The etiology of the liver cirrhosis was defined as viral: when the viral markers for hepatitis B virus (HBV) or hepatitis $\mathrm{C}$ virus (HCV) were positive; alcoholic: defined by the daily consumption of more than $80 \mathrm{~g}$ of ethanol in males and more than $60 \mathrm{~g}$ in females for more than 10 years and other causes: liver disease due to fat deposits or cryptogenic.

The serologic detection of hepatitis B and C virus and HIV were carried out using a second generation ELISA test (Abott's diagnostic kit).

Liver function tests were done on all patients including (reference values), alanine aminotransferase (ALAT) and aspartate aminotransferase (ASAT) $(<50 \mathrm{U} / \mathrm{L})$, total serum bilirubin $(<17 \mathrm{mmol} / \mathrm{l})$, albumin $(35-45 \mathrm{~g} / \mathrm{L})$, prothrombin time $( \pm 3 \mathrm{seg} / \mathrm{control})$, cholesterol $(<5,2 \mathrm{mmol} / \mathrm{L})$, glycaemia $(<6,1 \mathrm{mmol} / \mathrm{L})$ and creatinine $(<129 \mathrm{mmol} / \mathrm{L})$. These determinations were carried out with the blood chemistry autoanalizer HITACHI 902 according to the references of Roche Diagnostics. Hemoglobin (115-140 g/L in female and of 120$160 \mathrm{~g} / \mathrm{L}$ in males) and platelet count $(150-400 \times 10 \%$ ) were processed in the hematologic complex ABX Micro 60 and alpha-fetoprotein in the Ultra Microanalysis System (SUMA) $(<15 \mathrm{UI} / \mathrm{mL})$. (Diagnostic kits from Centro de Inmunoensayo, Havana, Cuba).

The anthropometric evaluation included mid-arm circumference (MAC) measured in centimeters, triceps skinfold thickness (TST) measured in millimeters and subscapular skinfold thickness (SST) in millimeters as has been established by norms. With the first two indicators, the arm muscle area (AMA) and arm fat area (AFA) were calculated. Patients were classified as undernourished or nonundernourished according to the values defined in the references consulted for skinfold thickness and mid-arm circumference in the Cuban population [15-17]. Particularly patients with ages that range between 60 and 65 years, were evaluated according to the recommendations established by the World Health Organization for patients over 60 years [18]. To minimize the intraobserver variation in the anthropometric measurements, the average of three consecutive measurements was taken. A metric measuring tape and well callibered skinfold caliper with a pressure of $10 \mathrm{~g} / \mathrm{mm}^{2}$ of contact surface (Holtain Ltd, Crymych, UK) was used. Measurements were taken midway between the tip of the acromion and the olecranon process, with the patient standing in a relaxed position. Nutritional evaluation was based on values of MAC, TST, SST, AMA, AFA compared with those of a health reference population [15-18]. The classification of malnutrition was based on the Berdasco [17] studies.

The humoral immune alterations were evaluated by assessing serum immunoglobulin (A, M, G and E) and the complement - components' $\mathrm{C} 3$ and $\mathrm{C} 4$. The quantitative measurement of immunoglobulin was carried out by the immunoturbidimethrics method (Futura System S.r.l, Italy). Reference values were: total count of immunoglobulin: 8-16 g/l, IgA: 0.70 - 4.00 g/l, IgM:0.40 - 2.30 g/l, IgG: 7.0 - 16.00 g/l and IgE: $25-350 \mathrm{kUI} / \mathrm{L}$. The reference values for $\mathrm{C} 3$ and $\mathrm{C} 4$ were $0.9-1.8 \mathrm{~g} / \mathrm{l}$ and $0.1-0.4 \mathrm{~g} / \mathrm{l}$ respectively.

Cellular immunity was evaluated by a total lymphocyte count carried out in the automated counter ABX Micro 60 (range: 1.2 to 3.2 $\mathrm{x} 10^{9} /$ ) and the delayed intradermal hypersensitivity test with 4 types of antigens: 2 of them composed by a mixture of intestinal bacteria (Shigella, Salmonella, Proteus mirabilis, Proteus vulgaris, Proteus rettgerri, Morganella morgani, Pseudomona, Klebsiella, Escherichia coli, Citrobacter sp, Enterobacter) and respiratory bacteria (coagulasenegative staphylococcus, coagulase-positive staphylococcus, alpha hemolytic Streptococcus, Pseudomonas, Klebsiella pneumoniae, Neumococo pneumoniae, Moraxella catharralis). The other two were the candidin and the tetanic toxoid. The injections were given in the left forearm, and the reading was done 48 hours after the antigen had been administered. The nodule was interpreted according to its diameter in the following way: normal if diameter was between 4 to 6 $\mathrm{mm}$, anergicor hypoergicif $0-3 \mathrm{~mm}$ and hyperergic if equal to or more than $7 \mathrm{~mm}$. The hypersensitivity tests enabled the classification of an individual as immunodeppressed when two or more intradermic tests had nodules smaller than $4 \mathrm{~mm}$.

All patients were asked for a written informed consent and the study received the approval of the ethics investigation committee of the institution.

\section{Statistical analysis}

Descriptive measures, the mean, deviation standard and median were applied on the quantitative variables and for the qualitative variables, absolute and relative frequency was applied. The analysis applied by contingency tables for qualitative variables was done using Pearson's Chi squared test. The non-parametric tests were used to analyze the differences in indicators of humoral and cellular immunity of independent groups (groups of patients divided by cause, stage of the disease and nutritional state); the U Mann Whitney or Kruskal Wallis test was applied to denote the differences between two or more than two independent groups respectively. The variance analysis ANOVA was used to compare the anthropometric indicators in the different Child Pugh stages, when necessary, an adjustment with posthoc Bonferroni test was used. A 5\% level of significance was adopted in all the analysis to denote differences as significant. The analysis was carried out using SPSS version 15.0 (Jaendel Scientific, USA).

\section{Results}

The majority of cirrhotics were of a viral cause, the hematologic and biochemical tests showed differences only in the behavior of the ALAT and ASAT enzymes which were higher in this group. Table 1.

In the cirrhotic group studied, the immunoglobulins were in normal range, however the complement components $\mathrm{C} 3$ and $\mathrm{C} 4 \mathrm{~g} / \mathrm{l})$ showed a certain tendency to the inferior normal limit, $0.96 \pm 0.36$ and $0.17 \pm 0.08$ respectively. Immunodeficiency was proved in 28 patients $(36.8 \%)$, of these, the majority had more than two intradermic tests with anergy or hypoergy, most evident with candidin and the respiratory bacterias. The total lymphocyte count didn't show alterations with a mean between normal values, $1.7 \pm 0.8 \times 10 \%$.

In the analysis of humoral immunity according to the three groups of causes, only $\mathrm{C} 4$ showed significant differences with the lower values in alcoholics and viral. Although alcoholics showed the highest average of IgA values, they didn't significantly exceed the other two groups. Anergy and hipoergy for candida and bacteria of the respiratory tract were more evident in groups of cirrhotics of viral etiology and of other causes although not significantly. Surprisingly, alcoholics showed an average of normal sized nodules in the three of the four intradermic tests carried out. Table 2 .

Similar results were obtained in the total lymphocyte count, 
Citation: Castellanos MI, Seijas OR, González D, Ronquillo M, del Rosario Abreu M, et al. (2011) Immune Alterations in Liver Cirrhosis: Its Relationship with Etiology, Child Pugh Stage and Malnutrition. J Nutr Disorders Ther 1:101. doi:10.4172/2161-0509.1000101

Page 3 of 8

\begin{tabular}{|l|l|l|c|l|}
\hline Indicator & Viral (55) & Alcohol (11) & Other causes (10) & $\boldsymbol{P}$ Value \\
\hline Hemoglobin (g/l) & $122,5 \pm 21,8$ & $117 \pm 22,8$ & $111,7 \pm 15,0$ & 0,133 \\
\hline Platelets (10 $/ \mathrm{l})$ & $144,5 \pm 57,3$ & $144,7 \pm 50,1$ & $145,9 \pm 72,7$ & 0,876 \\
\hline ALAT (UI/l) & $80,8 \pm 60,2$ & $38,9 \pm 14,7$ & $36,7 \pm 30,8$ & $0,003^{*}$ \\
\hline ASAT (UI/l) & $89,8 \pm 66,8$ & $60,0 \pm 26,6$ & $47,7 \pm 34,2$ & $0,045^{*}$ \\
\hline Albumin (g/l) & $39,0 \pm 5,8$ & $39,8 \pm 7,8$ & $41,6 \pm 4,5$ & 0,379 \\
\hline Bilirubin (mmol/l) & $28,8 \pm 43,2$ & $31,1 \pm 27,7$ & $17,3 \pm 6,8$ & 0,742 \\
\hline Prothrombin time (sec) & $16,5 \pm 3,6$ & $18,3 \pm 5,9$ & $15,3 \pm 3,8$ & 0,291 \\
\hline Cholesterol (mmol/l) & $3,9 \pm 1,0$ & $4,4 \pm 1,4$ & $3,8 \pm 0,9$ & 0,668 \\
\hline Glycaemia (mmol/l) & $6,2 \pm 5,7$ & $6,0 \pm 1,7$ & $5,9 \pm 2,0$ & 0,269 \\
\hline Creatinine (mmol/l) & $81,4 \pm 55,8$ & $81,0 \pm 25,0$ & $87,2 \pm 24,0$ & 0,509 \\
\hline Alpha fetoprotein (UI) & $16,2 \pm 27,3$ & $4,1 \pm 2,8$ & $18,0 \pm 43,1$ & 0,228 \\
\hline
\end{tabular}

ALAT: alanine aminotransferase, ASAT: aspartate aminotransferase, Mean \pm standard deviation, $\mathrm{P}$ : significance value

${ }^{*} \mathrm{P}<0.05$, Kruskal Wallis test

Table1: Hematologic and biochemical indicators of the three groups in the study.

\begin{tabular}{|l|l|l|l|l|}
\hline $\begin{array}{l}\text { Measurement } \\
\text { inmunoglobulins and } \\
\text { complement } \mathbf{( g / l )}\end{array}$ & Cause & \\
\hline & \multicolumn{5}{|l|}{ Viral (55) } & Alcohol (11) & Other causes (10) & P Value \\
\hline IgM & $1,8 \pm 0,07$ & $1,7 \pm 0,14$ & $1,6 \pm 0,15$ & 0,473 \\
\hline IgG & $7,9 \pm 0,06$ & $7,9 \pm 0.09$ & $7,6 \pm 0.17$ & 0,157 \\
\hline IgA & $2,45 \pm 0,15$ & $4,0 \pm 0,88$ & $2,6 \pm 0,45$ & 0,285 \\
\hline IgE ${ }^{\star *}$ & $107,8 \pm 10,72$ & $129,8 \pm 21,34$ & $88,8 \pm 24,70$ & 0,446 \\
\hline C3 & $0,94 \pm 0,04$ & $0,93 \pm 0,11$ & $1,13 \pm 0,13$ & 0,387 \\
\hline C4 & $0,17 \pm 0,08$ & $0,15 \pm 0,06$ & $0,25 \pm 0,90$ & $0,027^{*}$ \\
\hline Intradermic tests & & & & \\
(nodule size, mm) & & & & 0,677 \\
\hline Intestinal bacteria & $4,7 \pm 2,8$ & $4,2 \pm 2,6$ & $3,9 \pm 2,8$ & 0,447 \\
\hline Candidin & $3,0 \pm 2,7$ & $4,0 \pm 3,3$ & $3,1 \pm 2,8$ & 0,292 \\
\hline Tetanic Toxoid & $5,4 \pm 2,8$ & $4,3 \pm 2,8$ & $4,9 \pm 2,4$ & 0,767 \\
\hline Respiratory bacteria & $3,7 \pm 2,7$ & $3,9 \pm 3,9$ & $3,5 \pm 1,9$ & \\
\hline
\end{tabular}

C3 and C4: Complement components', Ig: immunoglobulin (A, M, G and E), Mean \pm standard deviation, $P$ : significance value.

${ }^{*} \mathrm{P}<0.05$, Kruskal Wallis test.

${ }^{* *} \lg \mathrm{E}(\mathrm{kUl} / \mathrm{L})$

Table 2: Humoral and cellular immunity in cirrhotic patients according to the cause of the disease.

independent of the etiology of cirrhosis; values above $1.2 \times 10 \%$, were obtained. The average values for total lymphocyte count for viral, alcoholic and other causes were $1.8 \pm 0.9 ; 1.5 \pm 0.7 ; 1.5 \pm 0.6 \times 10$ $9 / 1$ respectively $(\mathrm{P}=0.368)$.

In the viral group, $36.4 \%$ was classified as immunodepressed, whereas in alcoholic group was $45.5 \%$ and in other causes was $30.0 \%$.

The behavior of the humoral immunity indicators according to the Child Pugh stage was different. With the worsening of the disease, the IgA increased, while the components of the $\mathrm{C} 3$ and $\mathrm{C} 4$ complement decreased. The analysis of delayed intradermal hypersensitivity test for intestinal and respiratory antigens showed that patients in a Child Pugh $\mathrm{B}$ stage showed higher hipoergy than patients in stage $\mathrm{C}$. The response for candidin and tetanus toxoid was as expected with a tendency to hipoergy and anergy as the disease got worse. The differences were significant for intestinal bacteria and tetanus toxoid as shown in Table 3.

The average values for the total lymphocyte count showed a decreasing tendency: $1.9 \pm 0.9 \times 10 \%$ in Child A, $1.5 \pm 0.4 \times 10 \%$ in B and it reached values below normal in Child C stage, $1.0 \pm 1.1 \times 10^{9} /$, Graph 1.

The worsening of the disease made them prone to a bigger immunologic compromise, the major percentage of immunodepressed were in Child C stage with $71.4 \%$ while stages B and A were $52.9 \%$ and $28.8 \%$ respectively $(\mathrm{p}=0.034)$.

The results of the anthropometric evaluation of patients in the study are represented in Table 4 . The mean age in men was below that of women. In these, the repercussion of the disease over the body composition was more noticeable, evidenced in the progressive decrease of the relative indicators of adipose and muscular reserve with the worsening of the disease. However, in females, the decrease of MAC and AMA was evident between Child Pugh A and B, both cases with Child $\mathrm{C}$ stage were obese patients, which justifies the values of the anthropometric indicators. Overall, 48 undernourished patients were detected (63.2\%).

The analysis of the humoral immunity indicators according to the nutritional state, only reported significant differences in the average

\begin{tabular}{|c|c|c|c|c|}
\hline \multirow{2}{*}{$\begin{array}{l}\text { Measurement } \\
\text { inmunoglobulins and } \\
\text { complement }(\mathrm{g} / \mathrm{l})\end{array}$} & \multicolumn{3}{|c|}{ Child- Pugh stage } & \multirow[b]{2}{*}{$P$ value } \\
\hline & $A(52)$ & B (17) & C (7) & \\
\hline $\lg M$ & $1,69 \pm 0,54$ & $1,94 \pm 0,40$ & $1,87 \pm 0,29$ & 0,077 \\
\hline $\lg G$ & $7,86 \pm 0,50$ & $8,06 \pm 0,28$ & $8,10 \pm 0,37$ & 0,258 \\
\hline $\lg \mathrm{A}$ & $2,31 \pm 1,09$ & $2,93 \pm 1,54$ & $4,94 \pm 3.01$ & $0,019^{*}$ \\
\hline $\lg \mathrm{E}^{* *}$ & $97,54 \pm 77,00$ & $126,22 \pm 76,57$ & $147,41 \pm 79,06$ & 0,192 \\
\hline C3 & $1,05 \pm 0,35$ & $0,86 \pm 0,28$ & $0,53 \pm 0,17$ & $0,001^{*}$ \\
\hline C4 & $0,20 \pm 0,08$ & $0,13 \pm 0,07$ & $0,09 \pm 0,03$ & $<0,001^{*}$ \\
\hline \multicolumn{5}{|l|}{$\begin{array}{l}\text { Intradermic tests } \\
\text { (nodule size, mm) }\end{array}$} \\
\hline Intestinal bacteria & $5,0 \pm 2,7$ & $3,0 \pm 2,4$ & $5,0 \pm 3,0$ & $0,015^{\star}$ \\
\hline Candidin & $4,2 \pm 2,8$ & $3,0 \pm 2,7$ & $1,8 \pm 3,1$ & 0,629 \\
\hline Tetanic toxoid & $5,8 \pm 2,5$ & $4,0 \pm 3,0$ & $3,7 \pm 2,9$ & $0,028^{*}$ \\
\hline Respiratory bacteria & $3,7 \pm 2,8$ & $3,1 \pm 2,6$ & $4,5 \pm 3,5$ & 0,949 \\
\hline
\end{tabular}

C3 and C4: Complement components', Ig: immunoglobulin (A, M, G and E), Mean \pm standard deviation, $P$ : significance value

${ }^{*} \mathrm{P}<0.05$, Kruskal Wallis test

${ }^{* *} \lg \mathrm{E}(\mathrm{kUI} / \mathrm{L})$

Table 3: Humoral and cellular immunity in cirrhotic patients according to the Child Pugh stage.

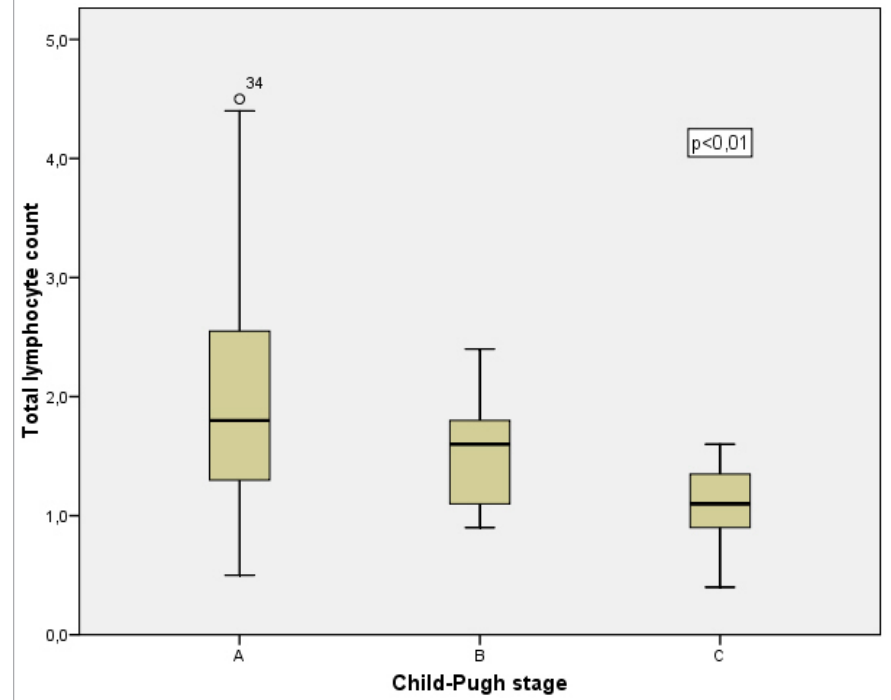

Total lymphocyte count $\left(\times 10^{9} / \mathrm{l}\right), P<0,01$, Kruskal Wallis test.

Graph 1: Total lymphocyte count according to Child Pugh stage. 
values of $\mathrm{C} 4$ in which a clear decrease of malnourished patients occurred with $0.16 \pm 0.08 \mathrm{~g} / \mathrm{L}$ compared to the non-malnourished $0,21 \pm 0,09 \mathrm{~g} / \mathrm{L}(P=0,025)$. The analysis of the results of the intradermic tests showed in the malnourished a higher immune compromise for candida and bacteria of the respiratory tract whose average nodule size was below $4 \mathrm{~mm}$. However in the non-malnourished, hipoergy was only seen in candida. Table 5.

The total lymphocyte count behaved in a similar way in both groups with $1.7 \pm 0.9 \times 10^{9} /$ in the malnourished and $1.7 \pm 0.7 \times 10^{9} / \mathrm{in}$ the non-malnourished $(P=0,368)$.

In relation to the state of immunocompetence, a higher percentage of immunodepressed in the undernourished was reflected, in comparison to the non-malnourished with $41.7 \%$ versus $28.6 \%$, however this was not statistically significant $(\mathrm{P}=0.254)$.

\section{Discussion}

The main cause of the disease under study was viral, which corresponds to what has been reported for the geographic area to which our country belongs [19-23]. The sample was chosen randomly, only with certain inclusion criteria, that's why the majority was expected to be of this etiology. Studies published in Cuba in relation to the etiology of the disease show viral hepatitis as the most frequent, specifically HCV [24]. HBV plays an important role in other lattitudes, however in the country, the application of vaccines against this virus in the population below 25 years and groups with greater risk have obtained a decrease in the incidence and prevalence in the last 15 years [25].

Less than $40 \%$ of patients were immunodepressed, this quantity can be considered as expected for a sample in which the majority maintained an acceptable liver function. It was interesting to see a major defect in the immune response to certain antigens like candida and bacteria of the respiratory tract.

Four characteristic types of infections have been described in cirrhotic patients, spontaneous bacterial peritonitis responsible for approximately $44 \%$, urinary tract infection with $25 \%$, pneumonia $15 \%$ and bacteria without a source in $5 \%$. According to this order, it would be logical to think that a patient is more prone to infection of enteric origin than of respiratory [26]. The intestinal flora alterations in cirrhotics caused by the abnormal colonization of the small intestine increased the probability that gram negative aerobic bacteria invade the blood stream and cause infections of enteric origin [27,28] However, the immune alterations observed in the study showed that the immunodepresion for germs of the respiratory tract was more, which constitutes an interesting finding.

Patients with cirrhosis are exposed to respiratory tract infections due to various causes like the decrease in the cough mechanism, the risk of aspiration in patients with encephalopathy and the invasive procedures that facilitate nosocomial infections which along with the leukopenia secondary to the base disease, alcohol consumption and the exposure to specific community infections like tuberculosis or influenza increase the risk of infections which can end up being serious [7]. Streptococcus pneumoniae is the most frequent etiologic agent of pneumonias in cirrhosis to which we can add gram negative bacillus like Klebsiella pneumoniae and Haemophilus pneumoniae respectively [29].

\begin{tabular}{|c|c|c|c|c|c|c|c|}
\hline Sex & $\mathbf{n}$ & Age (years) & MAC (cm) & TST (mm) & SST $(\mathrm{mm})$ & AMA $\left(\mathrm{cm}^{2}\right)$ & AFA $\left(\mathrm{cm}^{2}\right)$ \\
\hline & \multicolumn{5}{|c|}{ Male } & & \\
\hline Child A & 22 & $49,4 \pm 9,7^{*}$ & $30,5 \pm 3,3$ & $12,2 \pm 3,7$ & $14,2 \pm 8,2$ & $57,3 \pm 11,5$ & $16,7 \pm 6,4$ \\
\hline Child B & 11 & $46,7 \pm 8,6^{*}$ & $30,9 \pm 3,9$ & $12,7 \pm 5,1$ & $16,3 \pm 4,5$ & $58,2 \pm 13,3$ & $17,8 \pm 9,3$ \\
\hline \multirow[t]{2}{*}{ Child C ANOVA } & 5 & $43,8 \pm 6,6^{*}$ & $26,7 \pm 3,6$ & $10,6 \pm 4,2$ & $10,4 \pm 2,7$ & $43,7 \pm 8,8$ & $13,0 \pm 6,4$ \\
\hline & \multicolumn{5}{|c|}{ Female } & & \\
\hline Child A & 30 & $52,2 \pm 8,9^{*}$ & $32,0 \pm 4,3^{1}$ & $24,9 \pm 8,0$ & $24,5 \pm 9,6$ & $47,4 \pm 13,2^{2}$ & $34,6 \pm 13,1$ \\
\hline Child B & 6 & $53,3 \pm 4,5^{*}$ & $26,5 \pm 4,1^{1}$ & $21,1 \pm 9,8$ & $18,5 \pm 9,5$ & $31,9 \pm 5,9^{2}$ & $24,7 \pm 14,5$ \\
\hline $\begin{array}{l}\text { Child C } \\
\text { ANOVA }\end{array}$ & 2 & $51,0 \pm 0,1^{*}$ & $\begin{array}{l}28,7 \pm 0,3 \\
0,021\end{array}$ & $25,9 \pm 12,8$ & $12,2 \pm 2,5$ & $\begin{array}{l}34,3 \pm 12,1 \\
0,018\end{array}$ & $30,5 \pm 13,7$ \\
\hline
\end{tabular}

ANOVA: analysis of variance, AFA: arm fat area, AMA: arm muscle area, MAC: mid-arm circumference, SST: subscapular skinfold thickness, TST: triceps skinfold thickness

${ }^{*} \mathrm{P}<0,001$ male verses female according to Child Pugh stage, Student $\mathrm{T}$ test

$\mathrm{N}$ : number, Mean \pm standard deviation

Table 4: Anthropometric characteristics of patients according to sex and stage of the disease.

\begin{tabular}{|c|c|c|c|}
\hline Measurement inmunoglobulins and complement (g/l) & Malnourished (48) & Non malnourished (28) & $P$ Value \\
\hline $\lg M$ & $1,8 \pm 0,08$ & $1,6 \pm 0,06$ & 0,084 \\
\hline $\lg G$ & $7,9 \pm 0,07$ & $7,9 \pm 0.05$ & 0,702 \\
\hline $\lg \mathrm{A}$ & $2,8 \pm 0,27$ & $2,3 \pm 0,17$ & 0,429 \\
\hline $\lg \mathrm{E}^{* *}$ & $112,5 \pm 11,57$ & $101,6 \pm 14,15$ & 0,706 \\
\hline $\mathrm{C} 3$ & $0,9 \pm 0,05$ & $1,0 \pm 0,06$ & 0,518 \\
\hline $\mathrm{C} 4$ & $0,1 \pm 0,01$ & $0,2 \pm 0,01$ & $0,025^{*}$ \\
\hline \multicolumn{4}{|l|}{ Intradermic (nodule size, mm) } \\
\hline Intestinal bacteria & $4,2 \pm 2,7$ & $5,0 \pm 2,8$ & 0,142 \\
\hline Candidin & $3,1 \pm 3,0$ & $3,2 \pm 2,6$ & 0,845 \\
\hline Tetanic toxoid & $4,9 \pm 2,8$ & $5,8 \pm 2,6$ & 0,191 \\
\hline Respiratory bacteria & $3,4 \pm 2,7$ & $4,1 \pm 3,0$ & 0,352 \\
\hline
\end{tabular}

C3 and C4: Complement components', Ig: immunoglobulin (A, M, G and E), Mean \pm standard deviation, P: significance value

${ }^{*} \mathrm{P}<0.05$, Mann-Whitney Test

${ }^{* *} \lg \mathrm{E}(\mathrm{kUI} / \mathrm{L})$

Table 5: Indicators of humoral and cellular immunity in cirrhotic patients according to their nutritional state. 
The pool of germs used as allergens in the study in their majority inhabit the nasopharinx of healthy individuals, however in immunocompromised patients with a disruption of the natural defense barriers, they become pathogens [30]. More studies would be needed to clarify if the immonodepression detected for these microorganisms is translated as a major incidence of this type of infections.

Candida albicans is an opportunistic germ with a high incidence in immunocompromised patients, the liver is one of the main responsible in the immunologic equilibrium, that is why any affectation in its function will compromise the immune state, therefore patients with cirrhosis are prone to these type of infections [31].

The levels of $\mathrm{C} 4$ of the complement showed different behaviors according to the causes of cirrhosis, their mean values in alcoholics and viral were lower which corresponds to that reported in other studies $[1,32,33]$. The inefficient liver synthesis of this protein has been associated with an alteration in the opsonization and bactericide functions which is more evident in advanced stages of the disease. In the study, with the exception of one case, all patients in Child B and C stage were associated with these two causes (data not shown).

The cellular immunity was not different in the different causes; however, other studies have detected a higher anergy in cirrhotics of alcoholic origin [34-37]. Alcohol consumption can cause lymphopenia and a decrease in the capacity of blastic transformation and cytotoxicity of the natural killer cells [38].

The reduction of $\mathrm{C} 3$ and $\mathrm{C} 4$ and the hemolytic activity of the complement by alternate way can be as a result of an increased consumption or a decreased production due to liver insufficiency, the magnitude of the damages has been negatively correlated with the levels of these complement factors [32].

It has been demonstrated that the decreased concentrations of C3 are due to the circulation of endotoxins in blood which has been significantly associated, independently to other variables like the major frequency of infections and major mortality. The acquired C3 deficiency in patients with liver cirrhosis could explain an increased risk of infections through a deficit in the capacity of opsonization, although it has been reported that this parameter doesn't appear altered in a stable way in all patients $[39,40]$. In the study, results support this theory therefore with the worsening of liver function, a directly proportional decrease of these complement components were seen.

Of all immunoglobulins, only IgA showed substantial changes in its values, proportional to the progress of liver damage. IgA is the predominant antibody in seromucous secretions in the organism like saliva, tears, breast milk and respiratory tract secretions, gastrointestinal and genitourinary [41]. The increased levels of these immunoglobulins have been demonstrated in alcoholics and in patients with a worsening liver function. Evidence shows bacterial translocation as the main responsible, able to facilitate the passage of pathogen germs to the peripheral blood, the latter once there become associated with a series of molecular patterns like lipopolysaccharides, peptidoglycans and others, which are able to generate secretions from proinflammatory cytokines and the consequent activation of B cells and the synthesis of immunoglobulins [42].

The increased levels of IgA, IgG and the decrease in C3 has been seen in cirrhotics in the pre transplant period and has been associated to a higher risk of infection after surgery [43].

The majority of these patients show a decrease in cellular immunity, the activation and proliferation of incubated $\mathrm{T}$ lymphocytes with different immunostimulant products like the response to intradermic injection of antigens (late hypersensitivity) is more noteworthy in the non compensated [44-46]. The decrease in the total lymphocyte count and the depression in response to the intradermic tests seen in the study and its relation with the severity of the liver damage corresponds with other authors findings [47-50].

In a general way, the immundepression was more in advanced stages of the disease which is attributed to a lower synthesis of factors related with innate immunity and to the hyper catabolism to which the organism has been submitted to by the disease.

Although the exact mechanism of immunologic incompetence in cirrhosis is not clear, various authors have described a close relationship between the alteration of cellular immunity and the malnutrition of cirrhotic patients. Malnourished cirrhotics are more prone to have infectious complications due to immunologic deficiencies in the humoral and cellular response [2-7].

Studies show that in the case of alcoholics, a close relationship exists between malnutrition and immunodepression, however in the viral etiology; the immunologic alterations are attributed more to the severity of the hepatocellular lesion and to the alterations that the viral infection prints over the immune system [47]. In the alcoholic liver disease, the likelihood for infections increases and this is due partly to a deficit of micronutrients, trace elements and vitamins with anti-oxidizing functions that increases the susceptibility of cellular membranes to the lipid peroxidation [51].

Other authors have observed other abnormalities of the immune system such as an increase in the activation of $\mathrm{T}$ cells and a decrease in $\mathrm{B}$ cells in patients with alcoholic liver cirrhosis, but these changes have been attributed to a direct effect of alcohol or of its metabolites [52,53].

It was expected that males were grouped in larger proportions than females in Child Pugh B or C and that the decrease of anthropometric indicators in these advanced stages of the disease were more evident in both sexes. This behavior is related to the catabolic effects that the progression adds and its complications [21].

Although all hypotheses evoke malnutrition as a possible responsible factor or contributing of immunologic disorders in this type of patients, the results obtained in the study were contradictory, better nutritional state and worse immunologic state have been reported in cirrhosis of viral cause and vice versa for alcoholics [47].

It wasn't confirmed that a major immune involvement existed in malnourished patients, even though an important part of them were immunodepressed. Only a partial defect was reflected in the humoral response due to the decrease in the $\mathrm{C} 4$ components of the complement. Interventional studies have demonstrated the betterment in the defensive mechanisms in this type of patients with nutritional support [54].

Of all elements considered in the investigation, it was the stage of progression of the disease that best evidenced the immune response. Child Pugh stage is considered the main and most consistent predictor of mortality in cirrhotic patients. According to D'Amico [55], patients in Child Pugh A stage have a low risk of dying therefore it would be useful in this group to find more predictors of decompensation more than that of mortality, of which the immunologic could be found.

\section{Conclusions}

In liver cirrhosis, the major contribution to the distorted immune response is the Child Pugh stage. Malnutrition maybe has a possible influence. 
Citation: Castellanos MI, Seijas OR, González D, Ronquillo M, del Rosario Abreu M, et al. (2011) Immune Alterations in Liver Cirrhosis: Its Relationship with Etiology, Child Pugh Stage and Malnutrition. J Nutr Disorders Ther 1:101. doi:10.4172/2161-0509.1000101

Page 6 of 8

\section{Acknowledgements}

The authors would like to thank Dr. Kevin Peña, for participation in the editing the manuscript.

\section{References}

1. Fica A (2005) Diagnosis, management and prevention of infections in cirrhotic patients. Rev Chilena Infectol 22: 63-74.

2. Caly WR, Strauss E (1993) A prospective study of bacterial infections in patients with cirrhosis. J Hepatol 18: 353-358.

3. Norman K, Pichard C, Lochsa H, Pirlich M (2008) Prognostic impact of diseaserelated malnutrition. Clin Nutr 27: 5-15.

4. Plauth M, Cabré E, Riggio O, Assis-Camilo M, Pirlich M, et al. (2006) ESPEN Guidelines on Enteral Nutrition: Liver Disease. Clin Nutr 25: 285-294.

5. Chandra RK (1991) 1990 McCollum award lecture. Nutrition and immunity: Lessons from the past and new insights into the future. Am J Clin Nutr 53: 1087-1101.

6. Mendenhall CL (1992) Immunity, malnutrition, and alcohol. Alcohol Health and Research World 16: 23-28.

7. Mainous MR, Deitch EA (1994) Nutrition and infection. Surg Clin North Am 74 659-676.

8. Borum P (2001) Nutrient Metabolism. In: Gottschlich MM, Fuhrman MP Fuhrman KA, Holcombe BJ, Seidner DL. The science and practice of nutrition support, American Society for Parenteral and Enteral Nutrition. Kendall/Hunt, lowa: 17-29.

9. Bianchi G, Marzocchi R, Lorusso C, Ridolfi V, Marchesini G (2008) Nutritiona treatment of chronic liver failure. Hepatol Res 38: S93-S101.

10. Hirsch S, de la Maza MP, Gattas V, Barrera G, Petermann M, et al (1999) Nutritional support in alcoholic cirrhotic patients improves host defenses. J Am Coll Nutr 18: 434-441.

11. Bergheim I, McClain CJ, Arteel G (2005) Treatment of Alcoholic Liver Disease. Dig Dis 23: $275-284$

12. Campillo B, Richardet JP, Nhi P (2005) Enteral nutrition in severely malnourished and anorectic cirrhotic patients in clinical practice. Gastroenterol Clin Biol 29: 645 - 651

13. Prasad AS (2000) Effects of zinc deficiency on Th1 and Th2 cytokine shifts. J Infect Dis 182 (Suppl 1): S62-68.

14. Teran JC, McCullough AJ (2001) Nutrition in liver diseases. In: Gottschlich MM, Fuhrman MP, Fuhrman KA, Holcombe BJ, Seidner DL. The science and practice of nutrition support, American Society for Parenteral and Enteral Nutrition. Kendall/Hunt, lowa: 537-552.

15. Berdasco A, Romero del Sol JM (1989) Valores de pliegues grasos en adultos cubanos I Sexo masculino 20 - 59 años. Rev Cubana Aliment Nutr 3: 327-341.

16. Berdasco A, Romero del Sol JM (1990) Valores de pliegues grasos en adultos cubanos II Sexo femenino 20 - 56 años. Rev Cubana Aliment Nutr 4: 55-69.

17. Berdasco A, Romero del Sol JM (1998) Circunferencia del brazo como evaluadora del estado nutricional del adulto. Rev Cubana Aliment Nutr 12: 8690.

18. Informe del comité de expertos de la OMS (1995) Organización Mundial de la Salud. El estado físico: uso e interpretación de la antropometría. Adultos de 60 o más años de edad. Serie de informes técnicos Ginebra OMS 854: 441-80.

19. Schuppan D, Afdhal NH (2008) Liver cirrhosis. Lancet 371: 838-851

20. Bellentani S, Tiribelli C (2001) The spectrum of liver disease in the general population: lesson from the Dionysos study. J Hepatol 35: 531-537.

21. Kim WR, Brown RS, Terrault NA, El-Serag H (2002) Burden of liver disease in the United States: summary of to workshop. Hepatology 36: 227-42.

22. Méndez N, Aguilar JR, Reyes A, Dehesa M, Juárez A, et al. (2004) Etiology of liver cirrosis in Mexico. Ann Hepatol 3: 30-33.

23. Shepard CW, Finelli L, Alter MJ (2005) Global epidemiology of hepatitis C virus infection. Lancet Infect Dis 5: 558-567.

24. González I, Abdo AA, López O, Hernández JC, Samada M, et al. (2006) First 100 liver transplants at the medico-surgical research center (CIMEQ). Transplant Proc 38: 2473-2474.
25. Castañeda C (2006) Hepatitis B crónica en la infancia. Hepatología 2006 (1stedn) CIMEQ editorial. Havana: 231-43.

26. Toledo C, Flores C, Saenz M, Jiménez P, Tejero A, et al (1994) Infecciones bacterianas en la cirrosis hepática. Rev Méd Chile 122: 788-794.

27. García Tsao G (2001) Bacterial translocation: Do cause or consequence of descompensation in cirrhosis? J Hepatol 34: 150-155.

28. Runyon BA, Borzio M, Young J, Squier SU, Guarner C, et al. (1995) Effect of selective bowel decontamination with norfloxacin on spontaneous bacterial peritonitis, translocation, and survival in an animal model of cirrhosis. Hepatology 21: 1719-1724

29. Johnson D H, Cunha B A (2001) Infections in cirrhosis. Infect Dis Clin North Am 15: 363-371.

30. Murray PR, Barón EJ, Pfaller MA, Tenover FC, Yolken RH (1999) Manual of Clinical Microbiology. (7stedn), Washington D.C. ASM.

31. Tsuruta R, Oda Y, Mizuno H, Hamada H, Nakahara T, et al. (2007) Candida dubliniensis isolated from the sputum of to patient with end-stage liver cirrhosis. Intern Med 46: 597-600.

32. Talaat RM, Daif A, Salama M, El-Halafawy K A, Raouf A (2007) Serum Levels of Complement C1Q, C3 and C4 in Patients at Different Stages of Chronic Hepatitis Viral C Infection. World Journal of Medical Sciences 2 : 88-95.

33. Castillo MCG (1997) Función de los polimorfonucleares en la cirrosis hepática [tesis doctoral]. Madrid: Universidad Complutense [article in Internet].

34. Franco D, Belghiti J, Cortesse A, Boucquey BM, Charra M, et al. (1981) Nutrition et immunité du cirrhotique alcoolique. Gastroenterol Clin Biol 5: 839-846.

35. Mendenhall CL, Anderson S, Weesner RE, Goldberg SJ, Crolic KA (1984) Protein-calorie malnutrition associated with alcoholic hepatitis. Veterans Administration Cooperative Study Group on Alcoholic Hepatitis. Am J Med 76 : 211-222.

36. O'Keefe SJ, EL-Zayadi AR, Carraher TE, Davis M (1980) Malnutrition and immuno-incompetence in patients with liver disease. Lancet 20: 615-617.

37. Mills PR, Shenkin A, Anthony RS, McLelland AS, Main ANH, et al. (1983) Assessment of nutritional status and in vivo immune response in alcoholic liver disease. Am J Clin Nutr 38: 849-859.

38. MacGregor RR (1986) Alcohol and immune defense. JAMA 256: 1474-1479.

39. Wyke RJ, Naghovic JA, Eddleston AL, Williams R (1980) Defective opsonisation and complement deficiency in serum from patients with fulminant hepatic failure. Gut 21: 643-649.

40. Homann C, Varning K, Hagasen K, Mollnes T E, Graudal N, et al.(1997) Acquired C3 deficiency in alcoholic cirrhosis predispose to infection and increased mortality. Gut 40: 544-549.

41. láñez E (1999) Curso de inmunología general. Inmunoglobulinas y otras moléculas de células $B$.

42. Massonnet B, Delwail A, Ayrault JM, Chagneau-Derrode C, Lecron JC, et al.(2009) Increased immunoglobulin A in alcoholic liver cirrhosis: exploring the response of B cells to Toll-like receptor 9 activation. Clin Exp Immunol 158: $115-24$

43. Carbone J, Micheloud D, Salcedo M, Rincon D, Bañares R, et al (2008) Humoral and cellular immune monitoring might be useful to identify liver transplant recipients at risk for development of infection. Transpl Infect Dis 10: 396-402.

44. Girón-González SA, Alvarez-Mon M, Menéndez-Caro SL, Manzano L, Abreu $\mathrm{L}$, et al. (1994) $\mathrm{T}$ lymphocytes from alcoholic cirrhotic patients show normal interleukin-2 production but a defective proliferative response to polyclonal mitogens. Am J Gastroenterol 89: 767-773.

45. Yuceyar H, Kokuludag A, Coker A, Ersoz O, Keskinoglu A, et al.(1996) The serum levels of soluble interleukin-2 receptor levels in patients with obstructive jaundice. Hepatogastroenterology 43: 949-953.

46. Nouri-Aria KT, Alexander GSM, Portmann BC, Hegarty SE, Eddleston ALWF, et al. (1986) T and B cell function in alcoholic liver disease. J Hepatol 2: 195207.

47. Caly WR, Strauss E, Carrilho FJ, Laudanna AA (2003) Different degrees of malnutrition and immunological alterations according to the aetiology of cirrhosis: A prospective and sequential study. Nutr J 2: 1-10. 
Citation: Castellanos MI, Seijas OR, González D, Ronquillo M, del Rosario Abreu M, et al. (2011) Immune Alterations in Liver Cirrhosis: Its Relationship with Etiology, Child Pugh Stage and Malnutrition. J Nutr Disorders Ther 1:101. doi:10.4172/2161-0509.1000101

Page 7 of 8

48. Sobhonslidsuk A, Roongpisuthipong C, Nantiruj K, Kulapongse S Songchitsomboon S, et al. (2001) Impact of liver cirrhosis on nutritional and immunological status. J Med Assoc Thai 84: 982-988.

49. Rodríguez Félix L, Martín Santana A, Gutiérrez Fernández J, Zamora-Madaria $\mathrm{E}$ (1987) [Changes in cellular immunity, nutritional status and zinc deficiency in alcoholic liver cirrhosis]. Rev Clin Esp 180: 496-501.

50. Lombardo L, Capaldi A, Poccardi G, Vineis P (1995) Peripheral blood CD3 and CD4 T-lymphocyte reduction correlates with severity of liver cirrhosis. Int J Clin Lab Res 25: 153-156.

51. Moscarella S, Duchini A, Buzzelli G (1994) Lipoperoxidation, trace elements and vitamin $\mathrm{E}$ in patiens with liver cirrhosis. Eur J Gastroenterol Hepatol 6: 633-636
52. Laso FS, Madruga SI, López A, Ciudad J, Alvarez Mon M, et al.( 1996) Distribution of peripheral blood lymphoid sutsets in alcoholic liver cirrhosis: influence of ethanol intake. Alcohol Clin Exp Res 20: 1564-1568.

53. Spinozzi E, Agea E, Bassotti O, Belia J, Rondoni F, et al.(1993) Ethanol specific impairment of T-lymphocyte activation is caused by a transitory block in signal transduction pathways. Gastroenterology 105: 1490-1501.

54. Hirsch S, Maza M, Gatta's V, Barrera G, Petermann M. et al. (1999) Nutritiona Support in Alcoholic Cirrhotic Patients Improves Host Defenses. J Am Coll Nutr 18: 434-441.

55. D'Amico G, Garcia-Tsao G, Pagliaro L (2006) Natural history and prognostic D'Amico G, Garcia-Tsao G, Pagliaro L. Natural history and prognostic indicators of survival in cirrhosis: A systematic review of 118 studies. J Hepatol 44: 217-231. 